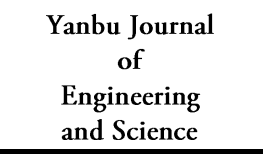

ISSN: 1658-5321
Vol. 8, April 2014 (1435H)

www.yjes.org.sa

\title{
EXPERIMENTAL INVESTIGATION OF THE PART-LOAD PERFORMANCE AND EMISSIONS OF A SPARK IGNITION ENGINE FUELLED WITH GASOLINE RON95 AND RON97
}

\author{
Taib Iskandar Mohamad ${ }^{1,2}$ and How Heoy Geok ${ }^{2}$ \\ 1 Department of Mechanical Engineering Technology, Yanbu Industrial College, Saudi Arabia \\ 2 Department od Mechanical and Materials Engineering, Faculty of Engineering and Built Environment, \\ Universiti Kebangsadn, Malaysia \\ Email:tmohamad@yic.edu.sa, taib@eng.ukm.my
}

\begin{abstract}
The effect of gasoline RON95 and RON97 on performance and exhaust emissions in spark ignition engine was investigated. The results were obtained from a 1.6 liter, 4cylinder Mitsubishi 4G92 engine with compression ratio 11:1. The engine was run at constant speed between 1500 and $3500 \mathrm{rpm}$ with $500 \mathrm{rpm}$ increment at various partload conditions from 0 to $5 \mathrm{Nm}$ with $1.25 \mathrm{Nm}$ increment. An engine control system, a hydraulic dynamometer and a portable exhaust gas analyzer were used to control engine operations and record engine performance, cylinder pressure and emissions data. Results showed that RON 95 fuel produced higher engine performance for both no-load and part-load tests condition. Gasoline RON95 produced 4.4\% higher brake torque, brake power, brake mean effective pressure as compared to RON97. The difference in engine performance between these two fuels was more significant at higher engine speed and loads. RON97 yielded $2.8 \%$ higher fuel conversion efficiency compared to that of RON95. RON97 fuel yielded 2.3\% lower brake specific fuel consumption throughout all load condition. In terms of exhaust emissions, RON95 fuel produced $7.7 \%$ lower NOx emission but higher CO2, CO and HC emissions by $7.9 \%, 36.9 \%$ and $20.3 \%$ respectively as compared to RON 97.
\end{abstract}

Keywords: Gasoline, Octane rating, Part load, Emission, Performance.

\section{INTRODUCTION}

Gasoline demand for motor vehicles has continued to expand due to an increasing number of individual user-owned motor vehicles and the growth of large automobiles' percentage share in the total shares of new vehicles. The rapid progress has been achieved in the development of low fuel consumption vehicles, supported mainly by engine technology, leading to the direct gasoline injection engine automobiles and debut of hybrid cars recently [1].The octane number requirement of an engine is defined as the minimum fuel octane number that will resist knock throughout the engine's operating speed and load range. The octane number of gasoline is one of the most important parameters in determining the fuel quality and influencing the engine performance and emissions of the vehicle [2].

The anti-knock or octane quality as indicated by the Research and Motor Octane numbers ( $\mathrm{RON}$ and MON), is a critical property of the fuel. RON and MON are determined in a single cylinder CFR (Cooperative Fuel 
Research) engine according to the ASTM procedures D-2699 and D-2700 respectively. The engine operating temperature and speed are both higher in the MON method compared to the RON method. Both the RON and MON scales are based on two paraffinic hydrocarbons which define the two ends of the scale; iso-octane is assigned the value of 100 and $n$-heptane the value of zero in both the scales. Blends of these two primary components are referred to as primary reference fuels (PRF) and define the intermediate points in the RON or MON scale. Thus a blend of $80 \%$ of isooctane and $20 \%$ of $n$-heptane by volume is assigned the octane number of 80 (PRF 80 ) in both RON and MON scales [3].

Every model of engine has different range of octane number requirements due to production tolerances and variations in engine (engine design and compression ratio (CR)) and vehicle conditions. In practice, people are believed that the higher-octane rating makes engine better in performance and it attracts people to use higher-octane gasoline. It was found that the trends to use higher-octane rating gasoline than engine requirement of vehicles with carburettor have increased the maintenance expenses. [4,5].

A number of studies [4-8] on the effect of octane number have been carried out. The study of Sayin et al. [4] using a low compression ratio engine $(8.0: 1)$ indicated that RON91 gasoline produced $4.2-4.8 \%$ higher power and 5.6\% lower brake specific fuel consumption (BSFC) than RON95 fuel. The results showed than RON91 fuel caused $5.7 \%$ and $3.4 \%$ respectively lower emissions of $\mathrm{CO}$ and $\mathrm{HC}$ due to the amount of tetra alkyl contained in the fuel. It was seen in this study that using higher-octane rating gasoline than the engine requirement did not augment effective engine performance, better fuel economy and emissions.

Another study of Akihama et al. [6] in a high CR (13.0:1) spark ignition direct injection (SIDI) showed that a high RON fuel, in particular one that is high in aromatics, yielded significant torque benefits under high load. The results showed that the torque and efficiency credit with high $\mathrm{RON}$ and high aromatic fuel were $13 \%$ and $21 \%$ compared with the base gasoline engine $(\mathrm{CR}=9.8)$. Duchaussoy et al. [7] has investigated the impact of RON on a turbocharged spark ignition (SI) engine. The study showed that the impact of RON was amplified and yielded benefits of an increase RON fuel due to the extreme conditions met on turbocharged gasoline engine. The impacts of the gasoline knock resistance affect the power, consumption and emissions of the engine.

According to Esterhuyse and Yates [8], it was found that emissions warrantees are not jeopardized if vehicles are operated on a market fuel with a lower octane (between RON91 and RON95) than the emissioncalibration reference fuel. The study revealed that only a very slight increase in THC (total unburned hydrocarbon) and in corresponding decrease in $\mathrm{CO}$ emissions with increasing RON. However, $\mathrm{NO}_{\mathrm{x}}$ had revealed no correction with RON. According to the mentioned works, using the correct gasoline requirement by the engine is more advantageous than using a higher or loweroctane gasoline for different type of engines and vehicles.

In Malaysia, since the last decade, the gasoline was sold in two grades; RON95 and RON97. Recently, the government increased the gasoline price by $15 \%$, as a result of global oil price hike. There have been major complain responding to this. People argued that they were denied from using higher grade (thus 
more power and better fuel economy) gasoline as a consequence. This has ignited an interest to look into this matter with respect to Malaysia's situation. Therefore, the objective of the project is to investigate the engine performance, fuel consumption and exhaust emissions of commercial grades RON95 and RON97 in a most commonly used 4-cylinder SI engine model; Mitsubishi 4G-series, which can be found in the national car, Proton, which represents the majority of road fleet in the country The outcomes of the investigation can justify the claim and perhaps correct view about RON number related to fuel economy, performance and emission.

\section{METHODOLOGY}

The engine used in the tests was a 1.6 litre, four-cylinder Mitsubishi 4G92 DOHC engine with compression ratio 11:1. The specifications of the engine are listed in Table 1 and the schematic diagram of the experimental setup is shown in Fig. 1.The engine was run at constant speed ranging from 1500 to $3500 \mathrm{rpm}$ with $500 \mathrm{rpm}$ increment at different engine load conditions from 0 to $5.0 \mathrm{Nm}$ engine loads with $1.25 \mathrm{Nm}$ increment. Fuels tested were PETRONAS (the Malaysia's National Petroleum Company) commercial grades gasoline with RON95 and RON97. The details of the both gasoline fuels are shown in Table 2. A hydraulic dynamometer was used to control the engine. The gasoline consumption was measured using a volume-scaled pipette and time recording. A pressure sensor (Kistler type 6125B) was installed to the engine cylinder and pressure data was sent to Dewetron DEWE5000 combustion analyzer. Cylinder pressure was monitored and IMEP was computed by DEWE5000 associated software to assure minimum spark advance for best torque (MBT) operation during the whole course of engine test. Kane-May portable exhaust gas analyzer was used to measure the exhaust emissions for both fuels.

TABLE 1 The SPECIFICATIONS OF MiTSUbishi 4G92 ENGINE

\begin{tabular}{|l|l|}
\hline Descriptions & Parameter \\
\hline Type & $\begin{array}{l}\text { In-line OHV, } \\
\text { DOHC }\end{array}$ \\
\hline Fuel system & $\begin{array}{l}\text { Port sequential } \\
\text { injection }\end{array}$ \\
\hline Combustion chamber & Pent-roof type \\
\hline Number of cylinder & 4 \\
\hline Number of valve & 16 \\
\hline Compression ratio & $11.0: 1$ \\
\hline Firing order & $1-3-4-2$ \\
\hline Displacement volume $\left(\mathrm{cm}^{3}\right)$ & 1597 \\
\hline Bore (mm) & 81 \\
\hline Stroke (mm) & 77.5 \\
\hline Connecting rod length (mm) & 120 \\
\hline $\begin{array}{l}\text { Maximum rated power } \\
\text { (kW/rpm) }\end{array}$ & $108 / 7000$ \\
\hline $\begin{array}{l}\text { Maximum rated torque } \\
\text { (Nm/rpm) }\end{array}$ & $149 / 4500$ \\
\hline
\end{tabular}

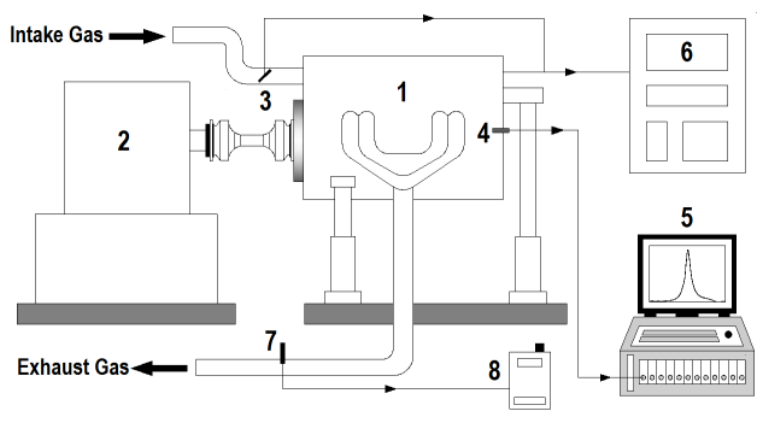

\begin{tabular}{|l|l|}
\hline 1. Engine & 5. Combustion analyzer \\
\hline 2. Hydraulic dynamometer & 6. Main controller \\
\hline 3. Throttle valve & 7. Oxygen sensor \\
\hline 4. Pressure sensor & 8. Exhaust gas analyzer \\
\hline
\end{tabular}

Fig. 1 Schematic of experiment setup

TABLE 2: PROPERTIES OF THE FUELS USED IN THE TESTS [9]

\begin{tabular}{|l|l|l|}
\hline Descriptions & RON95 & RON97 \\
\hline Research octane number & 95 & 97 \\
\hline Initial boiling point $(\mathrm{oC})$ & 35.7 & 35.7 \\
\hline Final boiling point $(\mathrm{oC})$ & 197.2 & 200.5 \\
\hline Density @ 15 oC $(\mathrm{kg} / \mathrm{L})$ & 0.764 & 0.7639 \\
\hline Reid vapour pressure $(\mathrm{kPa})$ & 66 & 65.5 \\
\hline
\end{tabular}




\section{RESULT AND DISCUSSION}

The performance of the engine with respect to brake torque, brake power, brake mean effective pressure (BMEP), fuel conversion efficiency (FCE), BSFC and exhaust emissions were investigated for RON95 and RON 97 fuels under various engine loads. All results were taken from measured experimental data except for BMEP (Fig. 4), BSFC (Fig. 5), and FCE Fig. 6), where calculations are based on Heywood [9]. Each point of the measured data were averaged over 1000 thermodynamic cycles and showed minimal error with low COV $(<1)$. Fig. 2 through 4shows the brake torque, brake power and BMEP of the engine at various engine loads from 1500 to $3500 \mathrm{rpm}$ for RON95 and RON97. The results show that RON97 fuel yields $0.4 \%-9.0 \%$ less brake torque, brake power and BMEP than that of RON95 throughout the speed range. On average, RON95 produces $4.4 \%$ higher brake torque, brake power and BMEP compared to RON97. The different of engine performance between these two fuels increases as engine load and speed increased as shown in Fig. 2 through 4 . The results are in agreement with the findings of Sayin et al. [4].The higher performance found in RON95 operations can be reasoned to the fact that this engine was designed for lower fuel octane rating, with relatively low compression ratio (11:1) for RON97 advantage, in which the advantage of higher RON cannot be realized to its maximum.

Fig. 5 presents the fuel conversion efficiency for RON95 and RON97 fuels at various engine loads. The term fuel conversion efficiency is preferred because it describes this quantity more precisely, and distinguishes it clearly from other definitions of engine efficiency [9]. It can be seen that the trend of FCE of RON95 is $0.2 \%-9.9 \%$ higher than that of RON97 fuel throughout the speed range. The results show that on average RON95 achieves 2.8\% better FCE compared to RON97. In terms of BSFC, RON97 shows lower BSFC at higher engine loads condition as shown in Fig. 6. On average, RON97 shows $2.3 \%$ slightly lower BSFC than that of RON95. This opposing behaviour of these two fuels with respect to FCE and BSFC can be explained by the variation of its properties. RON97 may have $97 \%$ of its content as isooctane, but remaining percentage includes many anti-knocking substances, not limiting to heptane. With $97 \%$ iso-octane, calorific value is higher thus the engine requires less fuel mass per unit power produced, resulting in lower BSFC. On the other hand, because RON95 possesses lower calorific value, but produces higher power on average, the FCE with this fuel is higher.

Since the tested engine is a naturally aspirated SI engine which operating parameters are correctly optimized by the manufacturer, higher octane rating cannot provide better power output under steady operation unless modification of both spark timing compression ratio are done. In addition, other parameters may require changes including valve timing and lift [11].

The exhaust emission results of $\mathrm{CO}_{2}, \mathrm{CO}$, $\mathrm{HC}$, and $\mathrm{NO}_{\mathrm{x}}$ for both RON95 and RON97 fuels are investigated in the study. The observations indicate that emissions of $\mathrm{CO}_{2}$ and $\mathrm{CO}$ of RON97 gasoline in overall are less than RON 95 throughout the speed range as shown in Fig. 7 and 8. CO is one of the most important emissions from IC engines. It is a result of incomplete combustion in engine and is generated when the engine is operated with a rich mixture or when proper air-fuel mixing is not achieved. On average, $\mathrm{CO}_{2}$ and CO emissions of RON97 are $7.9 \%$ and $36.9 \%$ respectively lower than that of RON95. 


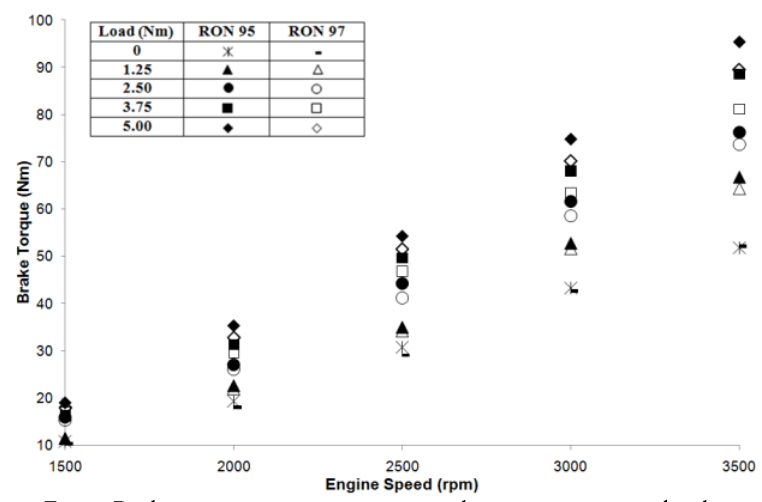

Fig. 2 Brake torque versus engine speed at various engine loads

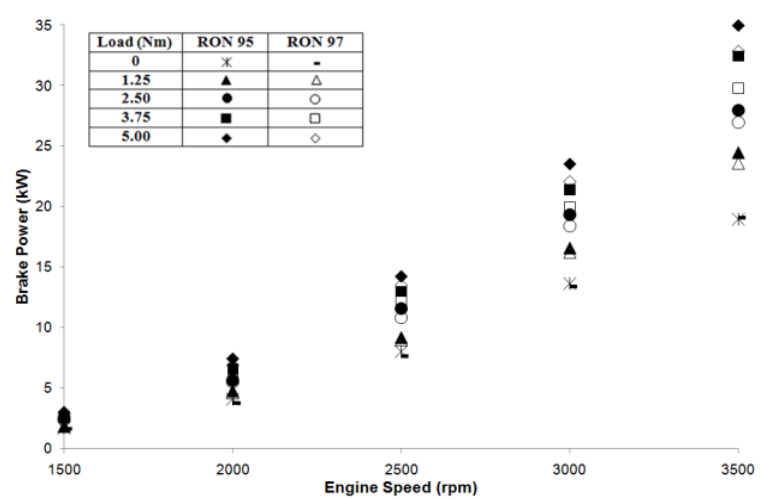

Fig. 3 Brake power versus engine speed at various engine loads

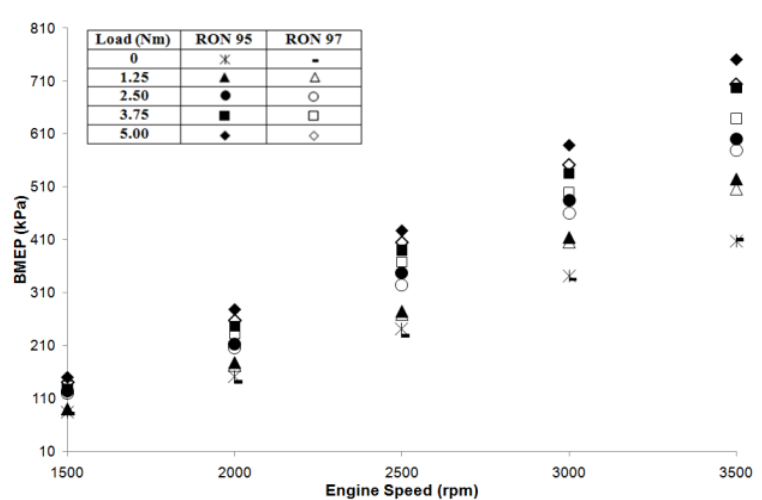

Fig. 4 Brake mean effective pressure versus engine speed at various engine loads

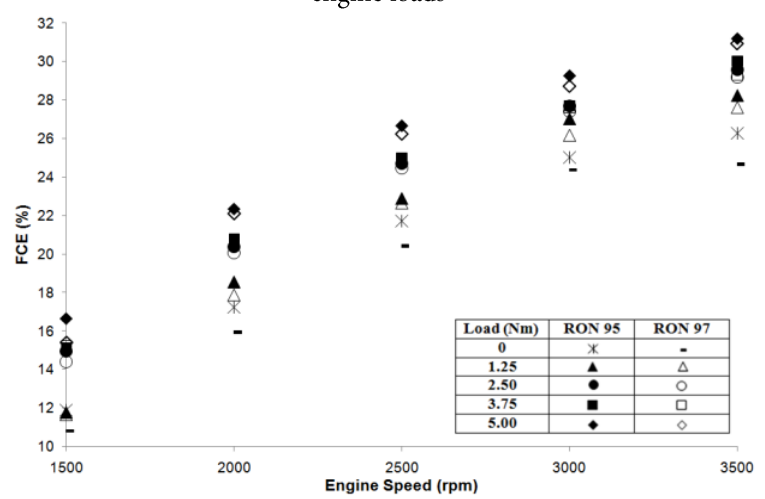

Fig. 5 Fuel conversion efficiency versus engine speed at various engine loads

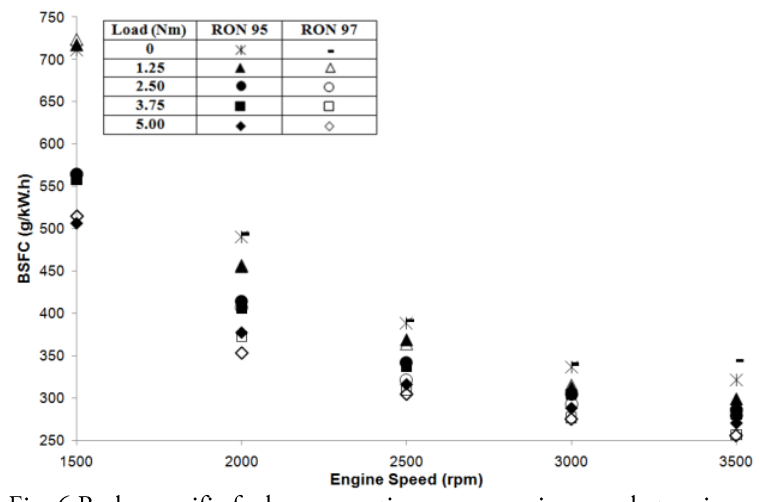

Fig. 6 Brake specific fuel consumption versus engine speed at various

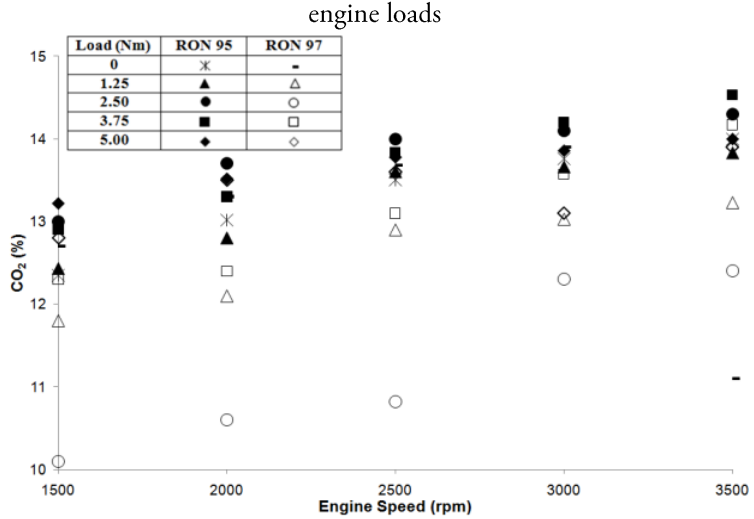

Fig. $7 \mathrm{CO} 2$ emission versus engine speed at various engine loads

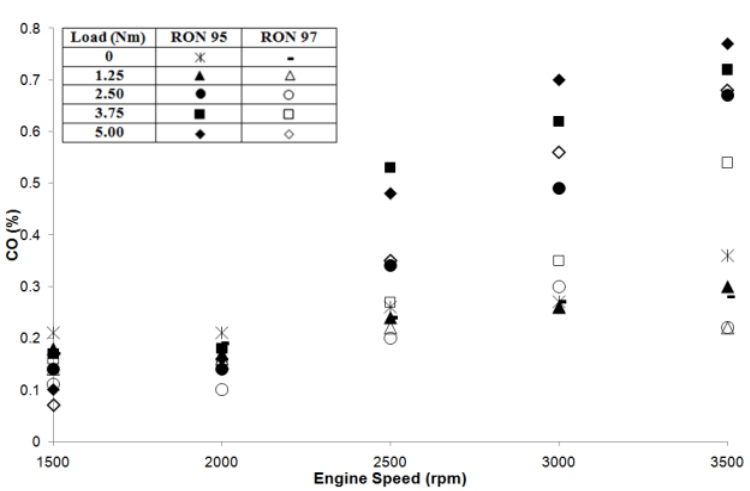

Fig. $8 \mathrm{CO}$ emission versus engine speed at various engine loads

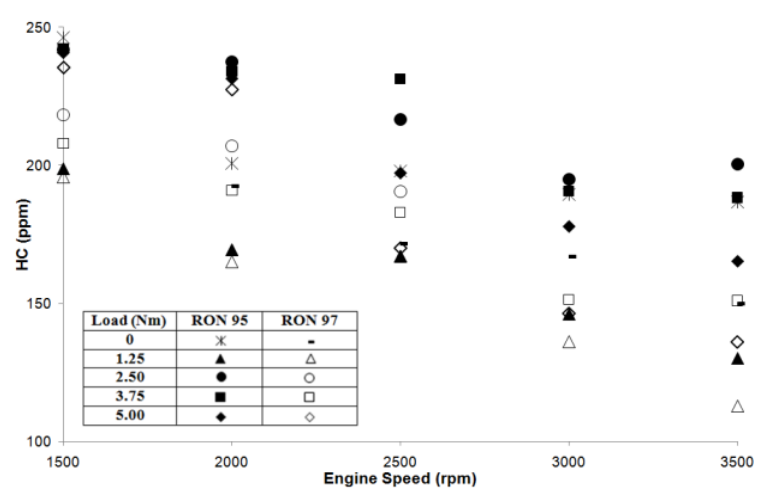

Fig. 9 HC emission versus engine speed at various engine loads 


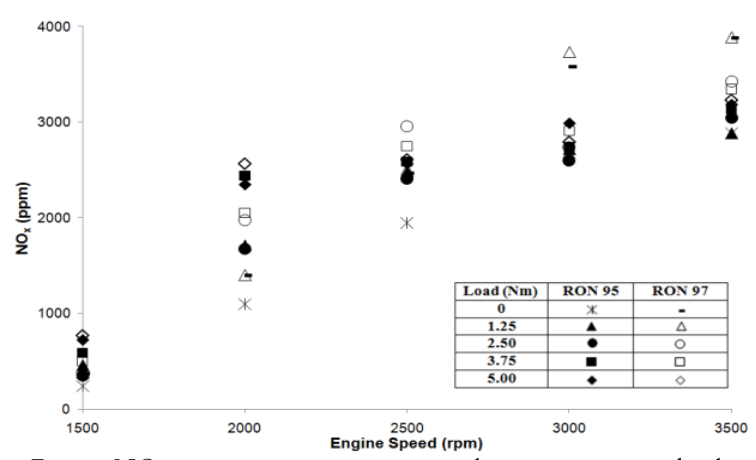

Fig. $10 \mathrm{NO}_{\mathrm{x}}$ emission versus engine speed at various engine loads

Unburned $\mathrm{HC}$ is another kind of undesired exhaust emission as a consequence of an unburned fuel-air mixture, and the other factors are incomplete combustion and presence of lubricating engine oil in the fuel or combustion chamber [9]. Fig. 9 shows that RON97 produces 20.3\% lower unburned hydrocarbon emission throughout the speed range as compared to RON95. The emission of $\mathrm{HC}$ decreases with increasing engine speed due to the improved combustion process.

$\mathrm{NO}_{\mathrm{x}}$ emissions cause forest damage (acid rain) and also act in combination with hydrocarbon to generate photochemical smog. The formation rate of $\mathrm{NO}_{\mathrm{x}}$ is increased with temperature and the amount of $\mathrm{NO}_{\mathrm{x}}$ generated also depends on the location within the combustion chamber. The highest concentration is formed around the spark plug, where the highest temperature and pressure occurs [10]. The emission of $\mathrm{NO}_{\mathrm{x}}$ of RON95 and RON97 gasoline fuels is presented in Fig. 10. The result shows that RON97 yields 7.7\% higher $\mathrm{NO}_{\mathrm{x}}$ emission compared to RON95 fuel. The emissions are increased with increasing engine speed as shown in Fig. 10.

The results of BSFC and emissions (except $\mathrm{NO}_{\mathrm{x}}$ ) for RON 97 are lower than that of RON 95. It is contrast with the study of Sayin et al. $[4,5]$ as their study indicated that lower RON fuel (RON91) produced lower BSFC and cleaner emissions compared to RON 95 fuel in a lower compression ratio of
8.0:1 engine. It is due to the different engine has different range of octane number requirement since both of the engine has different of engine specifications. In this engine testing, it is expected higher RON fuel is more suitable due to this used engine has higher CR (11.0:1).

Variation of emission data with respect to octane rating cannot be easily concluded due to the absence of fuel properties data. However, a simple explanation for lower CO2, $\mathrm{CO}$ and hydrocarbon emission from RON97 operations are due to better mixing and combustion, but this is penalized with higher NOx due to the expected higher combustion temperature from better combustion.

\section{CONCLUSION}

The effect of engine performance, fuel economy and exhaust emissions of RON95 and RON97 were studied previously [12]. In this work a more elaborated analysis were performed and reasoned. The following remarks can be drawn as the conclusions for this study:

- Under the same engine operations and configurations, RON95 fuel resulted in $4.4 \%$ higher brake torque, brake power and BMEP compared to that of RON97 fuel. The different of engine performance between these two fuels was significant revealed at higher engine speed and loads.

- RON97 produced $2.3 \%$ slightly better BSFC at higher engine loads but 2.8\% lower FCE compared to that of RON95.

- Emission of pollutant gaseous is significantly reduced by the use of RON97 with $7.9 \%, 36.9 \%$ and $20.3 \%$ respectively lower $\mathrm{CO}_{2}, \mathrm{CO}$ and $\mathrm{HC}$ emissions. However, RON 7 fuel produced $7.7 \%$ higher $\mathrm{NOx}$ emission compared to RON95. 
In conclusion, the engine performance, fuel economy and emissions results will definite vary for different types of engine with different specifications and requirements. For future work, it is suggested that to further investigate the fuel test for RON95 and RON97 in other SI engines with different compression ratio at wider engine speed range and open throttle opening operation to compare the engine performance, combustion characteristics and emissions in detail.

As for the impact of the results on the Malaysia's vehicle fuel techno-economics analysis for this engine model, with RON95 more power and better fuel economy are realized but with the penalty of higher emission levels compared to RON97.

\section{NOMENCLATURE}

$\begin{array}{ll}\text { ABDC } & \text { After bottom dead centre } \\ \text { ATDC } & \text { After top dead centre } \\ \text { BBDC } & \text { Before bottom dead centre } \\ \text { BMEP } & \text { Brake mean effective pressure } \\ \text { BSFC } & \text { Brake specific fuel consumption } \\ \text { BTDC } & \text { Before top dead centre } \\ \text { CFR } & \text { Cooperative Fuel Research } \\ \text { CO } & \text { Carbon monoxide } \\ \text { CO }_{2} & \text { Carbon dioxide } \\ \text { COV } & \text { Coefficient of variation } \\ \text { CR } & \text { Compression ratio } \\ \text { DOHC } & \text { Double overhead camshaft } \\ \text { FCE } & \text { Fuel conversion efficiency } \\ \text { HC } & \text { Hydrocarbon } \\ \text { MON } & \text { Motor octane number } \\ \text { NO } & \text { Oxides of nitrogen } \\ \text { OHV } & \text { Overhead valve } \\ \text { PRF } & \text { Primary reference fuels } \\ \text { RON } & \text { Research octane number } \\ \text { rpm } & \text { Revolution per minute } \\ \text { SI } & \text { Spark ignition } \\ \text { SIDI } & \text { Spark ignition direct injection } \\ \text { THC } & \text { Total unburned hydrocarbon } \\ & \end{array}$

\section{REFERENCES}

[1] T. Sakaguchi, "Influence of Diffusion of FuelEfficient Motor Vehicles on Gasoline Demand for Individual User Owned Passenger Cars," Energy Policy, vol. 28, pp. 895-903, 2000.
[2] K. Nagai, and T. Seko, "Trends of Motor Fuel Quality in Japan," JSAE Review, vol. 21, pp. 457-462, 2000.

[3] G.T. Kalghatgi, "Fuel Anti-Knock Quality - Part I. Engine Studies," SAE Technical Paper 200101-3584, 2001.

[4] C. Sayin, I. Kilicaslan, M. Canakci, and N. Ozsezen, "An Experimental Study of the effect of Octane Number Higher than Engine Requirement on the Engine Performance and Emissions" Applied Thermal Engineering, vol. 25, pp. 1315-1324, 2005.

[5] C. Sayin, and I. Kilicaslan, "Investigation of the effect on Engine Performance of Using Higher Octane Rating Gasoline than Engine Requirement," Erciyes Üniversitesi Fen Bilimleri Enstitüsü Dergisi, vol. 19, no. 1-2, pp. 11-17, 2003.

[6] K. Akihama, M. Taki, S. Takasu, T. Ueda, Y. Iwashita, J.T. Farrell, and W. Weissman, "Fuel Octane and Composition Effects on Efficiency and Emissions in a High Compression Ratio SIDI Engine," SAE Technical Paper 2004-011950, 2004.

[7] Y. Duchaussoy, P. Barbier, and P. Schmelzle, "Impact of Gasoline RON and MON on a Turbocharged MPI SI Engine Performances," SAE Technical Paper 2004-01-2001, 2004.

[8] N.J. Esterhuyse, and A.D.B. Yates, "A Study to Assess the Effect of Octane on Vehicle Emissions," SAE Technical Paper 2002-01-1664, 2002.

[9] J.B. Heywood, Internal Combustion Engines Fundamentals, McGraw Hill, New York, 1988.

[10] R.C. Ferguson, and A.T. Kirkpatrick, Internal Combustion Engines: Applied Thermosciences, 2nd edition, John Wiley \& Sons, New York, 2001.

[11] T. Cerri, G. D’Errico, A. Onorati, Experimental investigations on high octane number gasoline formulations for internal combustion engines, Fuel, Vol. 111, pp. 305-315, 2013.

[12] H. G. How, T. I. Mohamad, W. A. W. Ghopa, Y. Ali, S. Abdullah, A. A. A. Fauzi and S. Marhamah, Investigation of the Effect of Engine Performance and Emissions of RON 95 and RON 97 in Spark Ignition Engine, in the Proceedings of the International Conference On Sustainable Mobility (ICSM 2010), 1-3 December 2010, Kuala Lumpur, Malaysia. 


\title{
بحث معلدي لأداء محرك إحتراق داخلي مشعل بالثرارة تحت أحمال جزئية وانبعاثاته مستخدما بنزين 95 و97 رقم أوكتان
}

\author{
طيب إسكندر محمد1 وهاو هيو جيوك2 \\ 1 قسم تقنية الهندسة الميكانيكية_كلية ينبع الصناعيةـ المملكة العربية السعودية

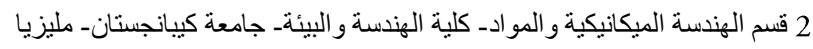

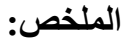

تم بحث تأثير إستخدام بنزين رقم أوكتان 95 و 97 على أداء و إنبعاثات العادم من محرك مشعل بالثرارة. وقد تم أخذ النتائج على محرك سعة 196 لتر ذو أربع إسطوانات ماركة ميتسوبيش(4 جي 92) بنسبة إنضغاط 11 إلى 1 ـ أجريت التجارب عند سرعات ثابتة للمحرك إبتاءا من 1500 إلى 3000 لفة بالقيقتبنسبة زيادة قدرها 500 لفة للاقيقة تحت مختلف الحمال الجزئية من صفر إلى 5 نيوتن متر وبزيادة تدريجية 1.25 نيوتن متر . تم إستخدام أنظمة التحكم والفرمله الهيدروليكية وجهاز تحليل العادمالمتنقل لتسجيل أداء المحرك وضغط الإسطو انة وبيانات الإنبعاثات .

وقد اظهرت النتائج أن إستخدام بنزين 95 رق أوكتان له اداء أفضل عند الحمل الصفري وكذللك الحمال الجزئية وقد اعطى 4.4 \% زيادة في العزم والقدرة والضغط الموثر المتوسط بالمقارنة ببنزين 97 رقم اوكتان. أما إختلاف اللداء ظهر عند السرعات والأحمال العالية فقد أظهر بنزين 97 رقم اوكتان 8.2\% أعلى في كفاءة التحويل عند مقارنته مع بنزين 95 رقم اوكتان واظهر 2.3 \% أقل في افستهلاك النوعي للوقود مع كل الأحمال الفرملية. أما بالنسبة لإنبعاثات العادم فإن بنزين 95 رقم اوكتان أنتج 7.7 \% أقل من أكاسيد النتروجين ولكنه اعلى في أكاسيد ثاني الكربون واول الكربون والهيدروكربون وكانت 7.9\% و 36.9 \% و 20.3\% على التو الي مقارنة بإستخدام بنزين 97 رقم اوكتان. 